\title{
Cerebral blood flow increase in cancer patients by applying cervical spinal cord stimulation
}

\author{
B. Clavo; F. Robaina; L. Catalá; M. Lloret; B. Pinar; M.A. Caramés; A. Ruiz; A. Cabezón; G. González; P. Lara; E. \\ Ruiz-Egea and M.A. Hernández
}

Dr. Negrín University Hospital. Las Palmas. (Canary Islands) Spain. (Stereotactic and Functional Neurosurgery Unit. Research Unit. Dep. Radiation Oncology. Radiology and Medical Physics) and ICIC (Canary Islands Institute for Cancer Research). Las Palmas. Spain.

Summary

Introduction. Generally, high-grade gliomas and head and neck tumors have decreased loco-regional blood flow resulting in reduced delivery of chemotherapy and oxygen, as well as an increases in radiation resistance to radiotherapy. The aim of this study was to analyze the effect of cervical spinal cord electrical stimulation (cSCS) on cerebral blood flow in patients with those tumors.

Patients and methods. We have evaluated 27 cancer patients with 12 with high grade gliomas and 15 with advanced head and neck tumors, who had cSCS devices placed after tumor diagnoses and before the commencementinitiating of radio-chemotherapy. They were 12 high grade gliomas and $\mathbf{1 5}$ advanced head and neck tumors. Before and after cSCS, cerebral blood flow was assessed bilaterally by transcranial Doppler.

Results. During cSCS there was a significant $(p<0.001)$ increase in systolic (mean $>22 \%)$ and diastolic $(>29 \%)$ blood-flow velocities in both, healthy and tumor middle cerebral arteries. The analyses by subgroup of tumors showed similarly significant outcomesfindings.

Conclusions. The results suggest that neuro-stimulationspinal cord electrical stimulation can increase cerebral blood flow in cancer patients. The implication is that this technique could be useful in modifying locoregional ischemia in brain tumors thus improveing the outcomes of after radio-chemotherapy. Further research is in progress to confirm the advantages of the technique.

KEY WORDS: Brain tumors. Cerebral blood flow. Ischemia. Spinal cord stimulation. Transcranial Doppler

Aumento del flujo cerebral en pacientes con tumores cerebrales y de cabeza y cuello mediante estimulación eléctrica medular cervical

Recibido: 16-02-06. Aceptado: 13-03-06
Resumen

Introducción. Los gliomas de alto grado y los tumores avanzados de cabeza y cuello generalmente tienen un flujo sanguíneo disminuido. Esto produce una disminución de la llegada de quimioterapia agentes quimioterápicos y oxígeno, lo que lleva a un aumento de la resistencia a la radioterapia y a la quimioterapia. El objetivo de este estudio fue analizar el efecto de la electroestimulación epidural de la médula espinal cervical (EME) sobre el flujo cerebral en pacientes con esos tumores.

Material y métodos. Hemos evaluado 27 pacientes oncológicos portando dispositivos de EME, que fueron colocados después del diagnóstico y antes de empezar el tratamiento con radio-quimioterapia. Se trata de $\mathbf{1 2}$ pacientes con gliomas de alto grado y 15 pacientes con tumores avanzados de cabeza y cuello. Antes y después de la EME se determinó bilateralmente el flujo sanguíneo en las arterias cerebrales medias mediante Doppler transcraneal.

Resultados. Durante la EME se produjo un aumento significativo $(\mathbf{p}<\mathbf{0 . 0 0 1})$ de la velocidad sistólica (mean media $\geq \mathbf{2 2} \%$ ) y diastólica $(\geq \mathbf{2 9 \%}$ ) del flujo en la arteria cerebral media, tanto del hemisferio ipsilateral al tumor como del hemisferio sano. El análisis por subgrupos de tumores mostró también resultados semejantes.

Discusión. Los resultados sugieren que la EME es capaz de aumentar el flujo sanguíneo cerebral en pacientes oncológicos. La principal implicación de este hallazgo sería su potencial utilidad para modificar la isquemia local y regional de los tumores cerebrales, y así intentar mejorar el efecto de la radioterapia y quimioterapia. Están en marcha estudios adicionales para confirmar los potenciales efectos beneficiosos de la técnica.

Abreviaturas. CBF: cerebral blood flow. cSCS: cervical-SCS. H\&N: head and neck. MCA: middle cerebral artery. PET: emission tomography. SCS: spinal cord electrical stimulation. SPECT: single photon emission computed tomography. TCD: transcranial Doppler 
PALABRAS CLAVE: Tumores cerebrales. Flujo cerebral. Isquemia. Estimulación medular. Doppler transcraneal.

\section{Introduction}

Generally, high-grade gliomas have a decreased locoregional blood flow, as demonstrated by studies with single photon emission computed tomography $(\mathrm{SPECT})^{11}$ or positron emission tomography $(\mathrm{PET})^{20}$. Ischemia results in reduced delivery of chemotherapy agents and oxygen. Hypoxic, but viable, tumor cells are up to 2.5-3 times more radio-resistant than well-oxygenated tumor cells ${ }^{10}$. Additionally, hypoxia can lead to a favored selection of tumor cells that have decreased apoptotic potential ${ }^{9}$ which, in turn, can result in additional resistance to radiotherapy and chemotherapy.

A meta-analysis ${ }^{22}$ has demonstrated that modification of tumor hypoxia during radiotherapy can increase improve local tumor control and patient's survival without increasing side effects in some tumors. In patients with malignant gliomas, some encouraging results have been obtained using hyperbaric chambers ${ }^{17}$ to overcome tumor hypoxia by increasing arterial-blood oxygenation. However, the scarcitylow of the equipment availability and the difficultly of coordinating its use with the patient's radiotherapy schedule reduces the technique's practicability. Vasoactive substances such as nicotinamide are easier to use but have not shown much effectiveness ${ }^{16,21,29}$ and overcoming locoregional ischemia in brain tumors remains an unresolved problem. Spinal cord electrical stimulation (SCS) is a neurosurgical technique used successfully for the treatment of ischemic diseases such as vasospastic syndromes ${ }^{24}$, peripheral vascular disease ${ }^{2}$ and angina pectoris ${ }^{12}$. In noncancer patients, cervical-SCS (cSCS) can increase blood perfusion in upper limbs and in head and neck (H\&N) tissues as well as improve cerebral blood flow (CBF). Increases in CBF during SCS have been demonstrated by the inhaled ${ }^{133} \mathrm{Xe}$ washout technique ${ }^{14}$, SPECT ${ }^{15}$, transcranial Doppler (TCD) ${ }^{19}$ and $\mathrm{PET}^{13}$. However, except for our own preliminary studies, there have been no investigations on the vascular effect of cSCS in cancer patients.

The aim of this present study was to evaluate the effect cSCS on blood flow in the middle cerebral artery (MCA) measured by transcranial Doppler in a series of cancer patients with carotid artery-dependent tumor blood flow.

\section{Material and methods}

\section{Patients}

We evaluated CBF, using TCD, in 27 cancer patients who had cSCS devices inserted. Patients were 22 males and 5 females with an overall mean age of 53 years (range 26-
70 years). The cancers tumors were 12 high grade gliomas and 15 advanced $\mathrm{H} \& \mathrm{~N}$ tumors.

TCD was performed after biopsy or surgery and before the commencement initiation of scheduled chemo-radiotherapy. Hemoglobin levels were recorded but not blood pressure, or cardiac parameters or smoking habit. Informed consent was obtained from all patients and the study was approved by the Institutional Ethical Committee.

\section{Cervical spinal cord stimulation}

cSCS was delivered via a Medtronic system (Medtronic Neurological, Minneapolis, MN). A tetrapolar electrode was percutaneously inserted under local anesthesia, and placed on the posterior surface of the spinal cord at C2-C4 level, in the epidural space. An external or subcutaneous impulse generator provided an adjustable range of pulse width, intensity and frequency of stimulation. Confirmation of the correct placement of the device was by provoking mild paresthesia in the upper limbs under test stimulation. The parameters of the stimulator were usually set at a voltage of 1-3 V, pulse width of $200 \mu \mathrm{sec}$ and a pulse frequency rate of $80-100 \mathrm{~Hz}$.

\section{Transcranial Doppler velocimetry}

Systolic and diastolic velocities (measured in $\mathrm{cm} / \mathrm{s}$ ) were recorded in both middle cerebral arteries (MCA) by TCD in the trans-temporal approach using a $2 \mathrm{MHz}$ probe from an Angiodine-2 Fluo-Link $300^{\circledR}$ device (DMS. Montpellier, France). Absence of stenosis was confirmed while the patient was alert, relaxed and seated. The insonation angle was $<60^{\circ}$.

In each patient, both TCD studies (pre- and post-cSCS) were performed bilaterally on the same day by the same radiologist to minimize inter-observer variation. TCD examinations were performed pre-cSCS and between 1 and 10 minutes post-cSCS. When an optimal stable flow image was obtained, recordings were made over at least three cardiac cycles. Each assessment was recorded at least three times to preclude operator or technical inaccuracy and the median values were used for subsequent statistical analyses.

\section{Statistical analysis}

Statistical tests were applied to the overall patient group as well as the two subsets of patients separately (those with glioma and those with H\&N tumor) The two-sided paired t-test was applied when comparing pre- and post-cSCS values. Data are expressed as mean $\pm \mathrm{SD}$. Linear correlation was assessed by Pearson's $r$ test. Differences were considered significant at a value of $\mathrm{p}<0.05$. 


\section{Results}

Following cSCS, in the overall study group, there was a significant increase $(\mathrm{p}<0.001)$ in systolic (Fig. 1) and diastolic (Fig. 2) velocities in the MCA of tumor and healthy MCAcerebral hemispheres. On the tumor side, systolic velocity increased by a mean of $22 \%$ (from $81 \pm 4$ to $98 \pm$ $5 \mathrm{~cm} / \mathrm{s}$ ) and diastolic velocity increased by $29 \%$ (from 34 \pm 3 to $43 \pm 3 \mathrm{~cm} / \mathrm{s}$ ). On the healthy side, systolic velocity increased by a mean of $24 \%$ (from $74 \pm 4$ to $92 \pm 4 \mathrm{~cm} / \mathrm{s}$ ) and diastolic velocity increased by $40 \%$ (from $30 \pm 2$ to $42 \pm 2 \mathrm{~cm} / \mathrm{s}$ ). Systolic velocity increased in all but one and diastolic velocity in all but four patients.

Similar results were obtained when both groups of patients were analyzed separately:

In brain cancer patients, the systolic velocity on the tumor side increased by a mean of $19 \%(p=0.002)$ and diastolic velocity increased by $18 \%(p=0.002)$. On the healthy side, systolic velocity increased by a mean of $30 \%$ $(\mathrm{p}<0.001)$ and diastolic velocity increased by $48 \%$ ( $\mathrm{p}<$ $0.001)$. In $H \& N$ patients, the systolic velocity on the tumor side increased by a mean of $21 \%(\mathrm{p}=0.002)$ and diastolic velocity increased by $26 \%(\mathrm{p}=0.004)$. On the healthy side, systolic velocity increased by a mean of $24 \%(p<0.001)$ and diastolic velocity increased by $40 \%(\mathrm{p}<0.001)$.

In our group of patients, there were no significant differences in resistance or pulsatility indices following cSCS and neither were there statistically significant correlations between TCD parameters and hemoglobin or hematocrit values.

Mean survival was $46 \pm 15$ months for grade III and $9 \pm$ 2 months for grade IV tumors.

\section{Discussion}

The increases of approximately $20 \%$ in systolic and diastolic velocities in the MCA following cSCS agree are in keeping with studies using TCD in non-cancer patients 19. Our results show a velocity increase in MCA suggesting that cSCS can induces an increase in regional blood flow in cancer patients and which, may potentially, could increase tumor blood flow in brain tumors.

The main limitation of our study is that TCD is not an indirect measurement of blood flow. The TCD technique measures blood flow velocities $(\mathrm{cm} / \mathrm{s})$ and velocity could be influenced by changes in the diameter of the vessel. However, cerebral arteries have relatively constant diameters in the course of assessment by TCD. It can be assumed that changes in MCA velocity correlate inversely with changes in vessel resistance and are related to changes in diameter of cerebral arterioles. Hence, TCD changes in MCA velocity should correlate with changes in cerebral blood flow ${ }^{1}$. The reported $50 \%$ increase in blood flow (in $\mathrm{ml} / \mathrm{min}$ ) during $\mathrm{cSCS}$ in the common carotid artery agrees with an

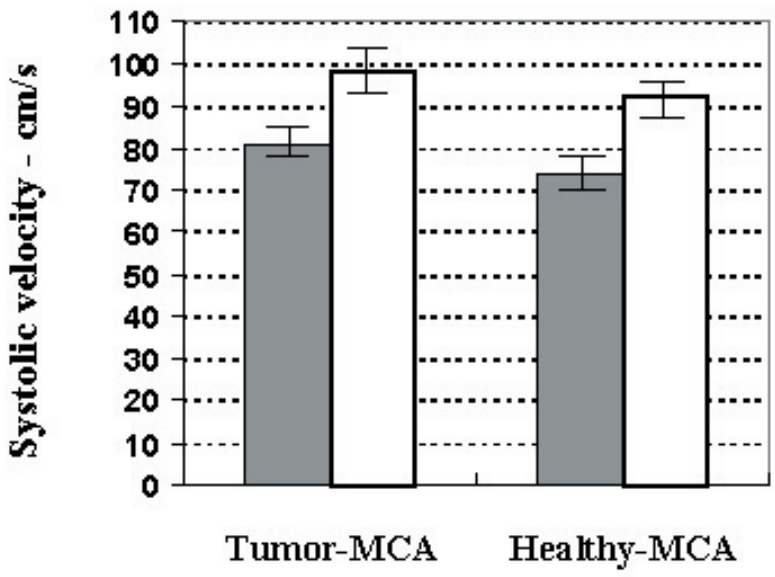

Figure 1. Systolic velocity in the middle cerebral artery (MCA) of cancer patients. Following cervical spinal cord stimulation (cSCS) the systolic velocity in MCA in healthy and tumor sides of the patient increased $>24 \%(p<0.001)$ and $>22 \%(p<0.001)$, respectively. Error bars show the 95\%. Confidence Intervals $(95 \% \mathrm{CI})$.

$\square$ pre-cSCS $\square$ post-cSCS

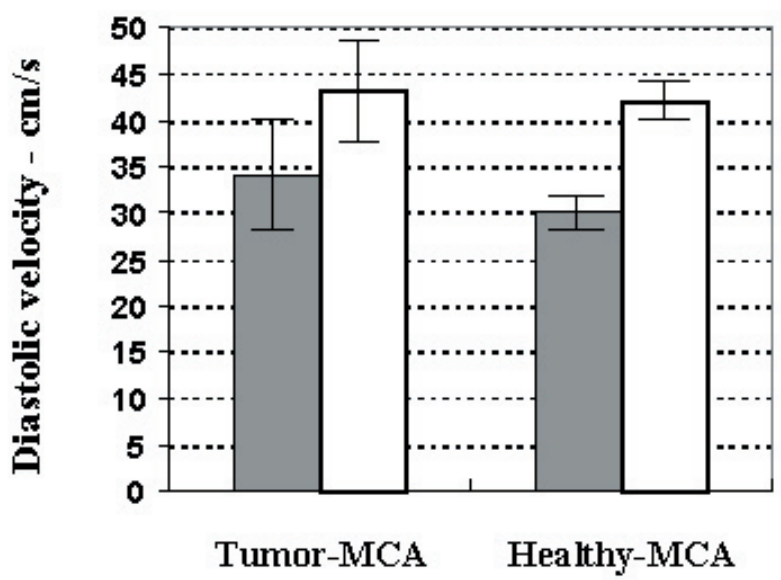

Figure 2. Diastolic velocity in the middle cerebral artery (MCA) of cancer patients. Following cervical spinal cord stimulation (cSCS), the diastolic velocity in MCA in healthy and tumor sides of the patient increased $>40 \%(p<0.001)$ and $>29 \%$ ( $p<0.001)$, respectively. Error bars show the $95 \%$. Confidence Intervals $(95 \% \mathrm{CI})$.

increased perfusion in the MCA, as has been demonstrated in experimental ${ }^{8}$ and clinical studies ${ }^{4}$.

The main hypothesis is that CBF increase could induce improvements in tumor perfusion. This hypothesis is supported by our SPECT-study in high-grade gliomas ${ }^{4}$ in 
which, following cSCS, blood flow in brain tumor areas was significantly increased by $15 \%$. This compares favourably with the reported "no-vascular effect" of carbogen breathing + nicotinamide in brain tumors ${ }^{16}$. This effect of cSCS on tumor blood flow has been reported in another SPECT-based study?.

It may be expected, that an increase in tumor blood flow should results in an increased tumor oxygenation. This is supported by our preliminary report in high grade gliomas using the polarographic probe technique with the Eppendorf device $^{3}$. The study showed that, during cSCS administration, median $\mathrm{pO}_{2}$ was significantly increased from 13 to 25 $\mathrm{mmHg}$ and the percentage of hypoxic values $<5 \mathrm{mmHg}$ was significantly decreased by $45 \%$. Based on radiobiological principles, the consequence of this effect would be an increased radio-sensitivity of the tissues. In addition, the CBF increase obtained induced by cSCS should improve at least in theory the regional delivery of chemotherapy agents, thus obtaining a higher local effect without increaseding systemic side effects. Special mention needs to be made regarding carmustine implants (Gliadel $\left.{ }^{\circledR}\right)$ where neuro-stimulation could increase liberation and absorption of carmustine this agent thus with a potentially increasinge in local side effects. However this potential risk effect needs to be confirmed and, in any case, the effect can be prevented -empted by switching-off the cSCS device during the first 3-4 weeks post-carmustine implantation. Changes in tumor blood flow and oxygenation during cSCS could also modify the tumor micro-environment and enhance the effect of some drugs as temozolomide (Temodal $\left.{ }^{\circledR}\right)$, as supported in our recent preliminary study using $\mathrm{PET}^{6}$. All the abovementioned effects of cSCS augur well for its use in an adjuvant approach in the treatment of brain tumors.

cSCS has a localized segmental vascular effect, particularly in brain, head and neck and upper limbs. Systemic effects are limited or absent and, as suchthus, the "steal effect", can be avoided as well as the side effects resulting from the use of vasoactive drugs such as nicotinamide ${ }^{21,19}$, can be avoided.

The vascular effects of cSCS can be explained by several mechanisms: sympathicolytic effect ${ }^{18,24,25,26}$, segmental liberation of vasoactive substances ${ }^{26}$ and the activation of vasomotor centers in the brainstem ${ }^{23,25}$ together with a competitive effect with $\mathrm{CO}_{2}$ on the mechanisms of $\mathrm{CBF}$ regulation ${ }^{19}$. Because of the anatomical and functional abnormalities of tumor blood flow $^{30}$, mechanisms to explain potential an increase in tumor blood flow increase awaitneed further and, more definitive, research. A possible hypothesis could be that defective self-regulation could preclude opposition to the local blood-flow increases produced by SCS, or that the host vessels in the tumor ${ }^{27}$ could induce some vessel reaction to the cSCS effect.

The technique of cSCS is minimally invasive and reversible. Following the placement of electrodes, the device can be activated or deactivated at any time over a period of several months, or even years, and can be activated to fit-in with the patient's radiotherapy or chemotherapy schedule. When required, the device can be safely removed.

In the present study, the effect of cSCS oin MCA flow was easily documented by TCD within a few minutes of initiating neuro-stimulation. We have not, as yet, established the optimum stimulation schedule to obtain a maximal effect in tumor blood flow, or oxygenation. Our previous experiences with contact-thermography technique in non-cancer patients ${ }^{24}$ and in two $\mathrm{H} \& \mathrm{~N}$ cancer patients ${ }^{5}$ showed that up to an hour of stimulation may be necessary to obtain the maximal effect in these tissues. Further studies are needed to optimize the this effect and the impact of cSCS on the survival of patients with brain tumors needs be evaluated.

Patients with high grade gliomas was included in the present study were treated using cSCS as adyuvant technique during the administration application of different radio-chemotherapy schedules. Though we did not observe an increased survival in our patients with high grade gliomas treated with cSCS, we believe that better results could be obtained using cSCS with the newer radio -chemotherapy schemes such as radiotherapy combined with concurrent temozolomide ${ }^{28}$.

In conclusion, the present study demonstrates that electrical cSCS increases the blood flow in the MCA of both cerebral hemisphers in cancer patients. As supported by previous studies, this regional CBF increase could improve loco-regional delivery of chemotherapy agents, radio-sensitizers and oxygen to brain tumors. The potential usefulness of cSCS as an adjuvant in radio-chemotherapy for high grade brain tumors merits deserves further investigation.

\section{Acknowledgments}

We thank all the nurses in the Stereotactic and Functional Neurosurgery and Chronic Pain Unit for their expertise and dedication. The study was supported, in part, by a grant from the Health and Research Foundation of the Autonomous Government of Canary Islands (Spain): FUNCIS 98-31. Scientific supervision was carried out by GICOR (Grupo de Investigación Clínica en Oncología Radioterápica). Editorial assistance was by Dr. Peter R. Turner of t-SciMed (Reus, Spain).

\section{References}

1. Bishop, C.C., Powell, S., Rutt, D., Browse, N.L.: Transcranial Doppler measurement of middle cerebral artery blood flow velocity: a validation study. Stroke 1986; 17: 913-915.

2. Broseta, J., Barberá, J., de Vera, J.A., et al.: Spinal cord stimulation in peripheral arterial disease. A cooperative study. J Neurosurg 1986; 64: 71-80.

3. Clavo, B., Robaina, F., Morera, J., et al.: Increase of 
brain tumor oxygenation during cervical spinal cord stimulation. Report of three cases. J Neurosurg 2002; 96: 94-100.

4. Clavo, B., Robaina, F., Catala, L., et al.: Increased locoregional blood flow in brain tumors after cervical spinal cord stimulation. J Neurosurg 2003; 98: 1263-1270.

5. Clavo, B., Robaina, F., Catala, L., et al.: Effect of cervical spinal cord stimulation on regional blood flow and oxygenation in advanced head and neck tumours. Ann Oncol 2004; 15: 802-807.

6. Clavo, B., Robaina, F., Montz, R., et al.: Modification of glucose metabolism in brain tumors using cervical spinal cord stimulation. J Neurosurg (in press).

7. Dario, A. Blood flow and cord stimulation. J Neurosurg 2004; 100: 357; author reply 357-358.

8. García-March, G., Sánchez-Ledesma, M.J., Anaya, J., Broseta, J.: Cerebral and carotid haemodynamic changes following cervical spinal cord stimulation. An experimental study. Acta Neurochir Suppl (Wien) 1989; 46: 102-104.

9. Graeber, T.G., Osmanian, C., Jacks, T., et al.: Hypoxiamediated selection of cells with diminished apoptotic potential in solid tumours. Nature 1996; 379: 88-91.

10. Gray, L.H., Conger, A.D., Ebert, M., Hornsey, S., Scott, O.C.A: The concentration of oxygen dissolved in tissues at the time of irradiation as a factor in radiotherapy. $\mathrm{Br} \mathrm{J}$ Radiol 1953; 26: 638-648.

11. Groshar, D., McEwan, A.J., Parliament, M.B., et al.: Imaging tumor hypoxia and tumor perfusion. J Nucl Med 1993; 34: 885-888.

12. Hautvast, R. W., Blanksma, P. K., DeJongste, et al.: Effect of spinal cord stimulation on myocardial blood flow assessed by positron emission tomography in patients with refractory angina pectoris. Am J Cardiol 1996; 77: 462-467.

13. Hautvast, R.W., Ter Horst, G.J., DeJong, B.M., et al.: Relative changes in regional cerebral blood flow during spinal cord stimulation in patients with refractory angina pectoris. Eur J Neurosci 1997; 9: 1178-1183.

14. Hosobuchi, Y.: Electrical stimulation of the cervical spinal cord increases cerebral blood flow in humans. Appl Neurophysiol 1985; 48: 372-376.

15. Hosobuchi, Y.: Treatment of cerebral ischemia with electrical stimulation of the cervical spinal cord. Pacing Clin Electrophysiol 1991; 14: 122-126.

16. Hulshof, M.C., Rehmann, C.J., Booij, J., van Royen, E.A., Bosch, D.A., González González, D.: Lack of perfusion enhancement after administration of nicotinamide and carbogen in patients with glioblastoma: a 99mTc-HMPAO SPECT study. Radiother Oncol 1998; 48: 135-142.

17. Kohshi, K., Kinoshita, Y., Imada, H., et al.: Effects of radiotherapy after hyperbaric oxygenation on malignant gliomas. Br J Cancer 1999; 80: 236-241.

18. Linderoth, B., Herregodts, P., Meyerson, B.A.: Sympathetic mediation of peripheral vasodilation induced by spinal cord stimulation: animal studies of the role of cholinergic and adrenergic receptor subtypes. Neurosurgery 1994; 35: 711-719.

19. Meglio, M., Cioni, B., Visocchi, M.: Cerebral hemodynamics during spinal cord stimulation. Pacing Clin Electrophysiol 1991; 14: 127-130.

20. Mineura, K., Sasajima, T., Kowada, M., et al.: Perfusion and metabolism in predicting the survival of patients with cerebral gliomas. Cancer 1994; 73: 2386-2394.

21. Miralbell, R., Mornex, F., Greiner, R., et al.: Accelerated radiotherapy, carbogen, and nicotinamide in glioblastoma multiforme: report of European Organization for Research and Treatment of Cancer trial 22933. J Clin Oncol 1999; 17: 3143-3149.

22. Overgaard, J., Horsman, M.R.: Modification of Hypoxia-Induced Radioresistance in Tumors by the Use of Oxygen and Sensitizers. Semin Radiat Oncol 1996; 6: 10-21.

23. Patel, S., Huang, D. L., Sagher, O.: Evidence for a central pathway in the cerebrovascular effects of spinal cord stimulation. Neurosurgery 2004; 55: 201-206.

24. Robaina, F.J., Domínguez, M., Díaz, M., Rodríguez, J.L., de Vera, J.A.: Spinal cord stimulation for relief of chronic pain in vasospastic disorders of the upper limbs. Neurosurgery 1989; 24: 63-67.

25. Sagher, O., Huang, D.L.: Effects of cervical spinal cord stimulation on cerebral blood flow in the rat. J Neurosurg 2000; 93: 71-76.

26. Sánchez-Ledesma, M.J., García-March, G., Goncalves, J., et al.: Role of vasoactive substances in the segmentary vasomotor response following spinal cord stimulation. An experimental study. Stereotact Funct Neurosurg 1990; 54-55: 224-231.

27. Schiffer, D., Chio, A., Giordana, M.T., Mauro, A., Migheli, A., Vigliani, M.C.: The vascular response to tumor infiltration in malignant gliomas. Morphometric and reconstruction study. Acta Neuropathol (Berl) 1989; 77: 369-378.

28. Stupp, R., Mason, W. P., van den Bent, M. J., et al.: Radiotherapy plus concomitant and adjuvant temozolomide for glioblastoma. N Engl J Med 2005; 352: 987-996.

29. van der Maazen, R.W., Thijssen, H.O., Kaanders, J.H., et al.: Conventional radiotherapy combined with carbogen breathing and nicotinamide for malignant gliomas. Radiother Oncol 1995; 35: 118-122.

30. Vaupel, P., Kallinowski, F., Okunieff, P.: Blood flow, oxygen and nutrient supply, and metabolic microenvironment of human tumors: a review. Cancer Res 1989; 49: 6449-6465.

Clavo, B.; Robaina, F.; Catalá, L.; Lloret, M.; Pinar, B.; Caramés, M.A.; Ruiz, A.; Cabezón, A.; González, G.; Lara, P.; Ruiz-Egea, E.; Hernández, M.A.: Cerebral blood flow increase in cancer patients by applying cervical spinal cord stimulation. Neurocirugía 2007; 18: 28-35.

Correspondence: Francisco Robaina, MD, PhD. Stereotactic and Functional Neurosurgery and Chronic Pain Unit. Dr. Negrín University Hospital. C/ Barranco la Ballena s/n. 35020 Las Palmas (Canary Islands). Spain. 


\section{Comentario al artículo Cerebral blood flow increase in cancer patients by applying cervical spinal cord stimula- tion de B. Clavo y cols.}

Los autores han observado que la estimulación eléctrica de la médula cervical induce un incremento significativo de la velocidad circulatoria sistólica y diastólica en las arterias cerebrales medias de ambos hemisferios cerebrales en una serie heterogénea de 27 pacientes portadores de gliomas cerebrales de alto grado, o tumores malignos de cabeza y cuello en comparación con el estado basal (previo a la estimulación). Dicho incremento fue similar en los dos subgrupos de pacientes con diferentes tipos de tumor intra o extracerebrales.

El propósito primario del tratamiento con estimulación eléctrica de la médula cervical fue incrementar el flujo local y la liberación de oxígeno en el seno de las neoplasias para hacerlas más susceptibles al tratamiento coadyuvante con quimio-radioterapia. Sin embargo, y como los autores reconocen, el doppler transcraneal determina el flujo cerebral de una manera indirecta y por ello imprecisa, y sus mediciones pueden estar influenciadas por los niveles de presión intracraneal, que aún siendo seguramente normales en el subgrupo de pacientes con tumores extracraneales, pudieron estar elevados en algunos pacientes portadores de gliomas. Por otra parte, la supervivencia media en los pacientes con gliomas fue la comúnmente observada con esta patología en pacientes tratados con quimio-radioterapia sin haber sido sometidos a estimulación de la médula cervical; por otra parte, el curso clínico en los pacientes con tumores de cabeza y cuello no se detalla. En cualquier caso, es casi impensable que el tamaño de la muestra en el presente estudio permitiera demostrar diferencias estadísticamente significativas en la supervivencia en comparación con enfermos tratados convencionalmente.
El lector imagina que el incremento en la velocidad de la circulación en las arterias cerebrales medias inducido por la estimulación eléctrica medular ocurre en el sujeto normal y no es privativa de los pacientes con cualquier tipo de cáncer. Por ello, antes de aplicar esta técnica de bajo riesgo, pero de alto coste, en una población de pacientes con gliomas cerebrales debería demostrarse que verdaderamente induce un incremento en el flujo y la liberación de oxígeno en el seno de los tumores. Además, y lo que es más importante, para demostrar que dicha técnica (cambie el flujo local tumoral en mayor o menor grado) mejora la respuesta terapéutica a la quimio o radioterapia, sería necesario incluir de manera aleatoria casos bien pareados (edad, Karnofski, tipo histológico y tamaño del tumor, grado de citorreducción determinado con RM en el inmediato postoperatorio, etc) en dos grupos suficientemente amplios de pacientes (control y tratado con estimulación medular) que recibieran quimio y radioterapia con protocolos similares y cuyo seguimiento fuera realizado por observadores que desconocieran cuales fueron expuestos al factor intervención (es decir, a estimulación eléctrica crónica de la médula cervical). Desafortunadamente, y como los autores reconocen, parece muy difícil realizar un estudio con un diseño suficientemente apropiado para alcanzar dicho objetivo. En cualquier caso, los autores deben ser alentados a proseguir su investigación para determinar la influencia de la estimulación medular en el flujo y metabolismo de los tumores cerebrales.

R. D. Lobato Madrid 